\title{
The Impact of Human Resources Development on Workers Productivity in Federal Polytechnic Idah, Kogi State Nigeria
}

\author{
Attah Amana Philip* \\ Department of Social Sciences and Humanities, Nigeria
}

Submission: April 21, 2017; Published: August 30, 2017

*Corresponding author: Attah Amana Philip, Department of Social Sciences and Humanities, Federal Polytechnic Idah, Kogi State Nigeria, Tel: +234-80-69619629; Email: philipfpi.paa@gmail.com

\begin{abstract}
The need for maximum optimality of intellectual capital to meet the desired goal of high productivity, competent and motivated manpower has been the desire of every Organization. Achieving this juicy objective needs a holistic and vigorous human resources development. This paper therefore examines the impact of human resources development on workers' productivity in Federal Polytechnic Idah, Kogi State Nigeria. Data were collected from both primary and secondary sources and analyzed using table, mean and five point's likert scale. The paper reviewed that human resources development is pivotal to employees productivity and the socio-economic fortunes of the citizens thus recommends that: the organization should synergize between human resources development and employees skills and ability, adequate fund should be provided to encourage human resources development and periodic review should be carried out to examine the extent to which human resources development has been accomplished.
\end{abstract}

Keywords: Impact; Human resources; Development; Productivity

\section{Introduction}

Human resources have played a significant role in the economic development in most developed countries such as United State of America, Britain and Japan among others. It can, therefore be concluded that a developing country like Nigeria, with its abundant natural resources and the necessary financial support can also experience such economic success if appropriate attention is given to the human resources development. Human resources development is the process of investing in people so that they are equipped to perform effectively. These processes are part of an overall human resource development approach that hopefully may result in people being motivated to perform better [1]. Human resources development is considered as critical factor for increasing productivity particularly in organizations that offers special services like tertiary institutions. Productivity on the other hand is the best use of different resources (as the inputs of the system), in the fulfillment of organizational goals. Productivity level of employees is influenced by a wide variety of skills, characteristics and attitudes. These include formal training and qualification, motivation levels, initiative, team skills, attention to detail Judgment, multi-task abilities, communication skills, general attitudes and work ethics. Human resources development is the most important factor for organizational success. Similarly the durability, continuation and success of an organization depend on the productivity of its work group [2].

The formal educational system does not adequately teach specific skills for a position in a particular organization. Few employees have the requisite skills, knowledge, abilities and competencies needed to work, as a result, many require extensive training to acquire the necessary skills to be able to make substantive contribution that will improve the productivity of the organization. If employees are to experience efficiency and effectiveness on the job, they need to acquire and develop knowledge and skills and if they are to believe that they are valued by the organization they work for, they need to see visible signs of management commitment to their development needs.

Human resources development of an employee is an issue that has to be faced by every organization. However, the amount, quality and quantity of human resources development carried out vary enormously from organization to organization. According to Cole (2002:132), factors that Influence the quantity and quality of human resources development activities include; the degree of internal change, the availability of suitable skills within the existing work-force and the extent to which management see human resources development program as a motivating factor that increase workers' Productivity. Many organizations meet 
their needs of human resources development in an ad hoc and haphazard manner, other organizations however, set about identifying their human resources development needs.

It is worth noting that Federal Polytechnic Idah since its inception in 1977 has a number of human resources development programs for its' staff. These programs are study leave, Sabbatical leave, Assistant lecturership scheme, Seminars, conferences, workshops, on the job training, and job rotation, but despite these development programms there has been no research work on the institution to determine whether the institution has achieved the needed productivity. There may have been several constraints to human resources development program in this institution. Constraints to human resources development programmes as noted by Onah [3] among others include, cooperate politics within the organizations, lack of good communication and feedback between the staff and management, inadequate human resources development programme and policy, insufficient funding and the inability of management to introduce the new wave of technology. All these greatly undermined the ability of workers of many organizations to improve in their performance which in turn impact on their productivity. Hence, this study will take into account the human resources development program of Federal Polytechnic Idah and appraise the impact of such programs on worker's productivity. As such, the work will be useful to both private and government agencies, educationist, and administrators in tertiary institutions who are concerned with human resources development and the society in general.

\section{Statement of the problem}

There have been a general resistance to investment in human resources development of workers in Organizations today, this is because it is believed that employees hired under a merit system are presumed to be qualified (Oris 2003:78). Therefore Information system regarding human resources development has not fully developed due to organizations giving less importance to human resources development programme: Various Studies have also been conducted to examine the relationship between human resources development and employees productivity. But a huge gap still exists in developing country like Nigeria, [4] however, observed that the attention given to the study of human resources development in tertiary institutions has not matched the seriousness which the concept deserves. It is in view of this that this study is being carried out to examine human resources development programme of the Polytechnic with a view to determining whether this low productivity is attributed to human resources development policy of the institution.

\section{Objective of the study}

The research principally examines the impact of human resources development in Federal Polytechnic Idah, Kogi State Nigeria. The paper also seeks to examine the relationship between human resources development and productivity.

\section{Hypotheses}

The researchers shall test these hypothetical statements.

\section{A. Hypotheses one:}

H0: The content of human resources development programs of Federal Polytechnic Idah is not relevant to employees' productivity.

H1: The content of human resources development programs of Federal Polytechnic Idah is relevant to employees' productivity.

\section{B. Hypotheses two}

Ho: selection of employees to participate in human resources development programs is not based on merit.

Hi: selection of employees to participate in human resources development programs is based on merit.

Scope of the paper.

This research is on the impact of human resources development on workers' productivity in Federal Polytechnic Idah, Kogi State Nigeria. The study will focus on human resources development, assessing the credibility for selection of employees for development and the emerging opportunities in human resources development. The periods cover between 2012 and 2016. This period was considered considering the fact that human resources development programs covers the period between 1-5 years.

\section{Review Literature}

\section{Literatures relevant to the study were reviewed}

4.1.2. The concept of human resources: Human Resources development (HRD) is the framework for helping employees develop their personal and organizational skills, knowledge, and abilities, it also include employees training and career development. The focus of all aspect of human resources development is on developing the most superior workforce so that the organization and individual employees can accomplish their work goal in service to customer and organization. Drucker [5] noted that, human recourses development means to develop available manpower through suitable methods such as training capable managers and transfers enhancing opportunities for career development. Human resources development programs create a team of well-trained, efficient and capable managers and subordinates. Such team constitutes an important asset of an enterprise. One organization is different from another mainly because of the people (employees) working therein.

Ezeani [6] saw the importance of human resources when he quoted [7] as observing that personnel of an organization comprises men and women young and old who are engaged in the production of goods and services and who are the greatest asset of the organization. It can therefore be inferred that the importance of human resources to the survival of an organization cannot be overlooked. Likert [8] in agreement with this assertion stated that the activities of any enterprise are initiated and determined by the persons who make up that institution. Thus plant, offices, computers, automated equipment and a 
modern firm are unproductive on their own except for human efforts and direction. Nwankwo [9] acknowledged the relevance and importance of human resources when he observed that there is no organization without human resource and even if an organization has got all the money and materials it needs, it must still find capable people to put them into effective use. The position of Nwankwo clearly underscores the relevance of human resources to any organization. Human resource must be viewed in the same context as the financial, technological and other resources that are managed in organization to increase productivity. The point of emphases by Nwankwo stems from the fact that other organizational resources like finance, machinery, and other physical resource cannot effectively and efficiently be utilized towards organizational goal attainment and survival without their manipulation by the human resources. Therefore, an organization whose human resources is inadequate will remain poor, unproductive, ineffective and in efficient. In conformity with Nwankwo, Oguniyi [10] maintained that no nation in the world can carry out any of its development programme without adequate and competent human resources. Corroborated this when he noted that the human resources of any nation hold the key to its survival, prosperity and future economic and social development. Ede [11] sees the human resources of any public or private organization as the most essential resources of that organization, it is human beings in the organization who can be well trained and developed intelligently to harness the other resources in such a way as to achieve organizational aims and objectives and ultimately ensure the survival of the organization.

In a similar contribution to the relevance of the human resources, Arua [12], noted that human resources sits at the commanding height of all other resources. It translates, activates and co-ordinate other resources such as money, material and machines in the production chain for useful purpose in order to achieve desired goals.

However, [5] asserts that the image of any organization or government is to a great extent reflected on the caliber and competence of staff that are vested with the responsibility of the implementation of its policies. [6] View is in tandem with [7] who posits that a good organizational structures does not by itself guarantee good performance. Human resources are as essential to the existence, survival and development of an organization as food is to human beings. The position of Drucker categorically shows the inevitability of the human resources to the organization thus. It is the live wire of any organization. Organizational resources like finance, machinery, building and other physical resources cannot be effectively utilized towards the attainment of the organizational goal without the manipulation by human resources. The belief here is that what set most organization up as successful organization is the human resources. Therefore, the success or failure of any organization is therefore dependent on its human resource [8-12].

\section{Relevance of human resources development}

Human resources development has always been an essential part of human life, particularly in the working environment. The concept of human resources development therefore predates history. Human resources development involves learning the skills needed for a particular job. It is a process by which employees systematically acquire basic skills, knowledge and attitude for efficient performance of their duties. Human resources development program as noted by Riggs [13] enables employees to learn or relearn acceptable job behavior, norms and practices for thorough job performance. The importance of Human resources development is more obvious given the growing complexity of the work environment, the rapid change in organization and advancement in technology. Human resources development helps to ensure that organization members take on new responsibilities and adapt to changing conditions. Supporting this view, Ibeku [14] noted that employees who have not received adequate training before being assigned responsibilities lack necessary confidence with which to carry out their job. He then recommended that an employee should be helped to grow into more responsibility by systematic human resources development program. This according to him is because training increases the employee's belief that he knows what is expected of him regarding the job and the knowledge which enables him originates ideas as to how best to carryout task of the job.

In a similar vein, Beach [15] noted that human resources development program at all levels is indeed indispensable if the nation expects a result oriented public service. Dessler [16] saw the changing nature of the world due to technological and scientific discovery and observed that as scientific discoveries are made, and changes in technology increases, coupled with the complex nature of the modern man, it becomes imperative that employees must be equipped to be able to cope with the development and changes and it is through the process of human resources development program that these added knowledge and skills can be acquired. Ezeani [6] noted that the human resources of an organization play a central role in its success or failure and to ensure optimum performance on the side of the employees, they must be provided with opportunities for constant training. Quoting Flippo [17] he said no organization has a choice of whether to develop employees or not, the only choice is that of method. Asuke \& Aniagulu [18] see employees as the greatest asset of the company and therefore to build their capacity is an investment. To them, after the initial process of matching the needs of the employees with the needs of the organization through employment process, the next stage of the contract for work is training; developing the employee's capacity to perform. The employees, they observed start their program as soon as they take up appointment with the organization. Supporting the position of Asuke \& Aniagulu [18] stated that employees need to be trained to keep up to date with the latest technology in the industry. He argued that one has either to move with time or be left behind.

Human resources development is vital. It is essential not only for affecting efficiency of administration but also for broadening the vision of the employees. It teaches them precision, makes 
them self-reliant and independent and develops in them capacity to take decisions and arrive at judgments. It enables employees adjust themselves to the new situation and comprehend the goals and values of the organization in which they work [19].

\section{Factors enhancing worker's productivity}

Productivity is a system or set of component whose function is to transform a set of inputs into some desired output. A component may be machine, man, tool, and part of the environment of the system. Krietner [20] stated that productivity is a measurement or calculation between inputs and outputs. Inputs are the amount of time and effort spent working, while outputs are the results. If the outputs are equivalent or more than inputs, the worker is considered productive. Productivity is linked to employee's quality of training and morale which are handled by human resources. When employees are happy at work they have more motivation, which increases productivity. Poor training and morale causes employees to be disengaged, or lower their productivity. The performance of an organization relies on the behavior of the employees. If employees are productive the Organization will be productive and gain value for stakeholders, if the employees are counterproductive the organization's performance will be negatively impacted upon and may even loose value. The performance of an organization's human resources development program is directly linked to productivity of the employees. Nwankwo GO [9] noted that, the part of human resources management that specifically deals with training and development of employees is human resources development unit, and it's functions include training an individual after he/she is hired, providing him or her opportunities to learn new skills, distributing resources that are beneficial for employee's tasks, and any other developmental activities that increases productivity [10] noted that, employees' productivity depend on the quality of training received, and the amount of time an individual is physically present on a job and also the degree to which he or she is "mentally present" or efficiently functioning while present at a job. Organization must address both of these issues in order to maintain high worker productivity, and this may occur through a variety of strategies that focus on employee satisfaction, health, morale and training [21]. Aguda \& Audu [22] acknowledged that apart from their basic qualifications, experience and skills needed to

\section{Research Methodology}

Table 1: Result of questionnaire on the relevance and content of human development programme.

\begin{tabular}{|c|c|c|c|c|c|c|c|c|c|c|}
\hline \multirow{3}{*}{ S/No } & \multirow{3}{*}{ S/No } & \multicolumn{5}{|c|}{$\begin{array}{l}\text { No. of Respondents } \\
\text { (N) }\end{array}$} & \multirow{3}{*}{$\begin{array}{l}\text { Number of } \\
\text { Respondents }\end{array}$} & \multirow{3}{*}{$\begin{array}{c}\text { Total } \\
\text { Score } \\
\text { (Fx) }\end{array}$} & \multirow{3}{*}{$\begin{array}{l}\text { Mean } \\
(\mathrm{X})\end{array}$} & \multirow{3}{*}{$\begin{array}{c}\text { Mean } \\
(\mathrm{X})\end{array}$} \\
\hline & & SA & $\mathbf{A}$ & $\mathbf{U}$ & D & SD & & & & \\
\hline & & 5 & 4 & 3 & 2 & 1 & & & & \\
\hline 1 & $\begin{array}{c}\text { Employees do } \\
\text { participate in } \\
\text { development } \\
\text { programme }\end{array}$ & 76 & 68 & 34 & 34 & 30 & 242 & 852 & 3.52 & Accepted \\
\hline
\end{tabular}

do a job, there are some other factors like absenteeism, high rate of labor turn-over, lack of commitment to work, laziness, waste of corporate time among others are practical parameters that could inhibit production and high productivity. According to [12], productive behavior and counterproductive behavior are opposite of each other. Productive behavior relates to the behavior that increases productivity, and this type of behavior is "defined as employee behavior that contributes positively to the goals and objectives of the organization". Noted that productive behavior promotes, encourages, and aids an organization in its purpose, but counterproductive behavior does not. Adam [23] stated that innovative technology is one way that employers can boost productivity. Having automated electronic processes for certain tasks can free up employee's time so that they can maximize their efficiency with other tasks. Bamiro [24] observed that increasing employees' productivity is key component in growing organization revenue. Management must take several steps to help increase productivity for the long-term. When an organization takes time to understand and implement the factors that improve productivity in the workplace, it is making a positive investment in the organization's future. Onah [25] sees productive workforce as one that understands their jobs and are given the freedom to reach their goals, by offering them comprehensive training and an putting efficient monitoring system in place, employees can learn to be more proactive in the execution of their duties. Krietner [20] stated that productivity directly affects an organization's profit. When employees are productive they accomplish more in a given amount of time. In turn, there efficiency saves their organization money in terms of time and labor. When employees are unproductive, they take longer time to complete projects, which cost employers more money due to the lost time. McGhee et al. [26] observed that even when every one of the positive productivity factors are present, productivity can be slow or stopped by real or imagined barrier. These roadblocks can include individual resistance to change, corporate politics, personal jealousies, corporate rivalries, as well as poor human resources development program. In addition, there may be perceived or imaginative barriers that keep employees from even attempting any effort aimed at increasing productivity or innovation. In both cases human resources need to work with managers in order to develop processes for identifying imagined barriers to productivity. 


\begin{tabular}{|c|c|c|c|c|c|c|c|c|c|c|}
\hline 2 & $\begin{array}{l}\text { The areas of } \\
\text { human resources } \\
\text { development is } \\
\text { relevant to my duties }\end{array}$ & 69 & 76 & 35 & 33 & 29 & 242 & 849 & 3.51 & accepted \\
\hline 3 & $\begin{array}{l}\text { The content being } \\
\text { taught is needful to } \\
\text { my job. }\end{array}$ & 68 & 79 & 35 & 38 & 22 & 242 & 859 & 3.55 & accepted \\
\hline 4 & $\begin{array}{l}\text { Adequate fund } \\
\text { are provided } \\
\text { for employees } \\
\text { development }\end{array}$ & 50 & 30 & 100 & 40 & 22 & 242 & 772 & 3.19 & Rejected \\
\hline 5 & $\begin{array}{l}\text { The skills being } \\
\text { acquired are } \\
\text { adequately utilized } \\
\text { after the programme. }\end{array}$ & 75 & 70 & 35 & 30 & 32 & 242 & 852 & 3.52 & Accepted \\
\hline 6 & $\begin{array}{c}\text { Employees are } \\
\text { motivated due to } \\
\text { their development }\end{array}$ & 48 & 45 & 85 & 40 & 24 & 242 & 779 & 3.22 & Rejected \\
\hline 7 & $\begin{array}{c}\text { There is less } \\
\text { industrial dispute } \\
\text { due to employees' } \\
\text { development. }\end{array}$ & 72 & 73 & 35 & 33 & 29 & 242 & 852 & 3.52 & accepted \\
\hline
\end{tabular}

This study was conducted in Federal Polytechnic Idah, Kogi State; Nigeria. The focus group within the area of study is the employees. Two hundred and sixty eight (268) questionnaires were distributed but two hundred and fourty two (242) were returned giving a response rate of $90 \%$. The responses were analyzed with the aid of table and arithmetical mean. A five point likert scale was used for making analysis. The "Agree - Disagree" response pattern was employed. Weights were also assigned to responses as shown in Table 1 one. The decision rule was to accept any element with arithmetical mean score (x) of 3.5 and above, and reject those with less than 3.5.

\section{Research Design}

This research utilized the social survey techniques for the study. The design involves data collection through the technique of questionnaire application. The questionnaire method of sourcing data was employed as it is time saving and less expensive in drawing information from the larger population available for the study. It also gives the respondents a great level of confidence in being anonymous in their decision making because, some of the respondents cannot have a face to face contact with the researcher. The researchers choose $95 \%$ confidence level for the study.

\section{Study Area}

The Federal Polytechnic, Idah was chosen as area of study for the research. The institution was established in February 1977 as Idah College of Technology. Its establishment was an attempt to solve practical problems facing the Nigerian economy. Advancement will depend on the availability of competent crops of skilled manpower in science, technology and vocational professions in the institution. The Polytechnic is located in Idah Local Government Area of Kogi State. Kogi state is in the southern guinea savannah ecological zone and lies between latitude $70 \mathrm{~N}$ and 8031 'N and longitude 50E and 60 15"E. Idah lies on the East bank of the lower Niger, south of Lokoja, the Kogi state capital and North of Onitsha in Anambra State. Idah served as the capital of the ancient Igala kingdom over which the king (Known as the Attah Igala) exercised a great influence. The vernacular spoken in Idah local Government and its environs is Igala [27-29].

By the time the institution commenced in November 1977, there was eleven (11) academic staff, one hundred and ninety nine (199) senior administrative staff and eighty six (86) supporting staff. Since then, the Federal polytechnic has grown in line with the demands of expansion.

\section{Measurement of Variables}

The dependent variable is human resources development while the independent variable is workers'Productivity, these variables are measured on a well structured questionnaire which is the research instrument used for the study. The questionnaire was administered in Federal Polytechnic Idah, Kogi State, Nigeria. The researchers and two field assistants implemented the process and the questionnaires were administered within a period of six weeks.

\section{Data Presentation and Analysis}

A. Sources: field research. (2013): The result of the data analyzed in Table 1 shows that the employees agreed that they do participate in development program of the institution, the areas of human resources development is relevance to their duties; the content being taught is needful to their job, the skill being acquired are adequately utilized after the programme. This is because they all show arithmetic mean of 3.50 and above except responses' which show that adequate fund are not provided for employees development and that employees are not adequately motivated to enable them put their effort enthusiastically. The duo have arithmetic mean below 3.50 . 
B. Sources: field research (2013): The result of data analyzed in Table 2 shows that the employees agreed that their selection for development programme is based on merit, there is free flow of communication in the institution, and that there is cordial relationship among employees in the Institution. This is because they all show arithmetic mean of 3.50 and above except two responses which show that there is disparity of pay package among employees and that there is no adequate facilities that would have enhance productivity in the institution since they have arithmetic mean below 3.50 .

Table 2: Result of questionnaires on the objectivity in selecting employees for development programme and how its affect their productivity.

\begin{tabular}{|c|c|c|c|c|c|c|c|c|c|c|}
\hline \multirow{3}{*}{ S/No } & \multirow{3}{*}{$\begin{array}{l}\text { Validation } \\
\text { Statement }\end{array}$} & & \multicolumn{4}{|c|}{$\begin{array}{l}\text { Number of Respondents } \\
\text { (N) }\end{array}$} & \multirow{3}{*}{$\begin{array}{l}\text { Number of } \\
\text { Respondents } \\
\text { (N) }\end{array}$} & \multirow{3}{*}{$\begin{array}{l}\text { Total } \\
\text { Scole } \\
\text { (Fx) }\end{array}$} & \multirow{3}{*}{$\begin{array}{l}\text { Total } \\
\text { Scole } \\
\text { (Fx) }\end{array}$} & \multirow{3}{*}{$\begin{array}{c}\text { Total } \\
\text { Scole } \\
\text { (Fx) }\end{array}$} \\
\hline & & SA & A & $\mathbf{U}$ & D & SD & & & & \\
\hline & & 5 & 4 & 3 & 2 & 1 & & & & \\
\hline 1 & $\begin{array}{c}\text { Selection of } \\
\text { employees for } \\
\text { development } \\
\text { programme is based } \\
\text { on merit. }\end{array}$ & 78 & 66 & 36 & 32 & 30 & 242 & 856 & 3.54 & Accepted \\
\hline 2 & $\begin{array}{l}\text { There is free flow of } \\
\text { information }\end{array}$ & 75 & 73 & 50 & 23 & 21 & 242 & 884 & 3.65 & Accepted \\
\hline 3 & $\begin{array}{l}\text { There is cordial } \\
\text { relationship among } \\
\text { employees in the } \\
\text { institution }\end{array}$ & 64 & 86 & 48 & 20 & 24 & 242 & 872 & 3.60 & Accepted \\
\hline 4 & $\begin{array}{l}\text { There is no disparity } \\
\text { of pay package } \\
\text { among employees. }\end{array}$ & 30 & 43 & 75 & 60 & 34 & 242 & 701 & 2.90 & Rejected \\
\hline 5 & $\begin{array}{l}\text { There is adequate } \\
\text { facilities in the } \\
\text { Institution }\end{array}$ & 32 & 41 & 73 & 64 & 32 & 242 & 703 & 2.90 & Rejected \\
\hline
\end{tabular}

\section{Conclusion}

From the study carried out, it was discovered that human resources development programme is carried out in Federal Polytechnic Idah. Respondents were of the view that effective human resources programme is important to any institution, and this can be achieved by effecting a good human resources development planning policies and training programme.

From the findings of this study, it can be concluded without dispute that, there is a relationship between human resources development and workers' productivity. Hence, the level of productivity of the staff of the institution is determined by the level of human resources development programmes available for the staff. Human resources development programmes are important factors in boosting employees' morals in any organization. Just as other motivating factors, employees desire training because it does not only enhance their chance for promotion but also increases their confidence on the job, reduce costs that are always attributed to ignorance and mediocrity, and also increases the institution output. Sadly though is the fact that the human resources department of the institution is bedeviled with myriads of problems.

\section{Recommendations}

Based on the findings from the work, the following recommendations are made for this study

1. The Federal polytechnic Idah through the personnel unit of registry department should plan and execute human resources development programmes that are in line with the objectives of the institution and those that match employee's ability and skills to enhance effective employees' performance.

2. The institution should widen the scope of its human resources development programmes so as to create opportunity for those who have not participated in the programmes to benefit.

3. Selection of employees to participate in human resources development programmes should be opened and strictly based on merit rather than on parochial interest. More so, the institution should sensitize its employees as regard to the imperatives of training and development.

4. As an aspect of development process, human resources development programmes should be integrated as fully as possible in the strategic plan of Federal Polytechnic Idah. In this regards, institutional and human resources development needs should be clearly defined and programmes strategy identified.

5. Management should ensure adequate funding of human resources development programmes, proper flow of information between the employees and management and a conducive working environment for her employees because they are the driving force of the institution. Finally there should be periodic assessment on the extent to which human resources development programme is implemented. 


\section{Current Trends in Biomedical Engineering \& Biosciences}

\section{References}

1. Britt TW, Jex SM Human Capital (2010) A theoretical \& Empirical Analysis with Special reference to education. ( $2^{\text {nd }}$ edn), Columbia University, New York, USA.

1. Craig R (2003) Education and Training for Public Management in Nigeria, University Publishing House, Onitsha, Nigeria.

2. Onah FO (1995) Training and Development in Nigeria Industries and Organization. John Jacobs Classic Publishers Ltd., Enugu, Nigeria.

3. Craig R (2010) The Theory and practice of Training. Kogan Page Ltd., London.

4. Njoku R (2005) Human Resources Management, A Critical Assignment on Personnel Administration. Logic gate Media Ltd, Aba, Nigeria.

5. Drucker FP (2007) The Practice of Management. New York, USA

6. Ezeani EO (2006) Fundamentals of Public Administration. Snap Press Ltd, Enugu, USA.

7. Ndiomu OA (2008) Personnel Management in Nigeria, London Macmillan publishers Co, USA.

8. Likert R (1974): The Human Organization: Its Management and Value. New York, USA.

9. Nwankwo GO (2007:17) Education and Training for Public Management in Nigeria. University publishing Company, Onitsha, Nigeria.

10. Oguniyi SO (1992) Manpower and Organizational Development. IIIorin: SESUN publishers. Student Comprehensive Hand book Revised Edition (2008) Mercypaul, Ibadan, Nigeria.

11. Ede KO (2005) Fundamentals of Manpower Training and Development. Athrep Publishers, Abuja, Nigeria.

12. Arua JS (2006) The public sector Enterprises and management in a Changing Environment. Aba, Cheedal Global Printing, Nigeria.

13. Riggs FW (2011) Administration in Developing countries. Houghton Miffin, Boston.
14. Ibeku C (2003) A Practical approach to Personnel Management. Gostak Printing Publishing Co. Ltd., Enugu, USA.

15. Beach DS (2000) personnel-The management of people at work: New York Macmillan, USA

16. Dessler G (2007) Human Resources Management. New Delhi, India.

17. Flippo E (1980) Personnel Management. London McGraw-Hill Book Company, USA.

18. Asuke GC, Aniagolu JN (2006) Human Resources Management and Leadership Effectiveness: The Nigeria Experience. Rocana Nigeria Ltd., Nigeria.

19. Bhagwan, V and Bhusan, V (2007) Public Administration. S. chand and Company Ltd., New Delhi, India.

20. Krietner S (1995) Nature of learning ( $1^{\text {st }}$ edn), Synene publishers London.

21. Aguda MA Audu YP (2000) A hand book of personnel management. A publication of soar multi-serve, Idah, Kogi, Nigeria.

22. Cluttbuck D (2001) Everyone Needs a Mentor ( $3^{\text {rd }}$ edn).

23. Adams EE (2009) Production and operation management. Columbia University press, USA.

24. Bamiro OA (2001) Introductory to business technology. Evans brothers Nigeria publishers limited, Nigeria.

25. Onah FO (2007) Strategic Manpower Planning and Development Nsukka.

26. McGhee (2007) the good manager's Guide, $\left(1^{\text {st }}\right.$ edn $)$, Synene publishers, London, USA.

27. Britt TW, Jex SM (2008) Organisational Psychology. A scientistpractitioner approach $\left(2^{\text {nd }}\right.$ edn $)$, New York, USA.

28. Cole GA (2002) Public and Human Resources Management, $\left(5^{\text {th }}\right.$ edn $)$ London.

29. Novit R K (2011) The Administrative Rules. Frank Lass press, London.

\section{Your next submission with Juniper Publishers} will reach you the below assets

- Quality Editorial service

- Swift Peer Review

- Reprints availability

- E-prints Service

- Manuscript Podcast for convenient understanding

- Global attainment for your research

- Manuscript accessibility in different formats

( Pdf, E-pub, Full Text, Audio)

- Unceasing customer service

Track the below URL for one-step submission

https://juniperpublishers.com/online-submission.php 